\title{
E3 Ubiquitin-Protein Ligase TRAIP
}

National Cancer Institute

\section{Source}

National Cancer Institute. E3 Ubiquitin-Protein Ligase TRAIP. NCI Thesaurus. Code C125108.

E3 ubiquitin-protein ligase TRAIP (469 aa, $53 \mathrm{kDa}$ ) is encoded by the human TRAIP gene. This protein plays a role in ubiquitination. 